\title{
Detection of SARS CoV-2 contamination in the Operating Room and Birthing Room Setting: Risks to attending health care workers
}

Authors: Patricia E. Lee ${ }^{1 *}$, Robert Kozak ${ }^{2}$, Nasrin Alavi ${ }^{3}$, Hamza Mbareche ${ }^{3}$, Rose C. Kung ${ }^{1}$, Kellie E. Murphy ${ }^{4}$, Darian Perruzza ${ }^{3}$, Stephanie Jarvi ${ }^{3}$, Elsa Salvant ${ }^{3}$, Noor Niyar N. Ladhani ${ }^{5}$, Albert J.M. Yee ${ }^{6}$, Louise-Helene Gagnon ${ }^{1}$, Richard Jenkinson ${ }^{6}$, Grace Y. Liu ${ }^{1}$

\section{Affiliations:}

${ }^{1}$ Divisions of Urogynecology and Minimally Invasive Gynecologic Surgery, Department of Obstetrics and Gynecology, Sunnybrook Health Sciences Centre, University of Toronto, Ontario, Canada

${ }^{2}$ Division of Microbiology, Department of Medicine, Sunnybrook Health Sciences Centre, University of Toronto, Ontario, Canada

${ }^{3}$ Sunnybrook Research Institute, Sunnybrook Health Sciences Centre, University of Toronto, Ontario, Canada

${ }^{4}$ Division of Maternal Fetal Medicine, Department of Obstetrics and Gynecology

Sinai Health System, University of Toronto, Ontario, Canada

${ }^{5}$ Division of Maternal Fetal Medicine, Department of Obstetrics and Gynecology

Sunnybrook Health Sciences Centre, University of Toronto, Ontario, Canada

${ }^{6}$ Division of Orthopedics \& Trauma Surgery, Department of Surgery, Sunnybrook Health Sciences Centre, University of Toronto, Ontario, Canada

*Corresponding author: Patricia E. Lee; pel.lee@utoronto.ca

Keywords

SARS-CoV-2, health care worker, environmental contamination, operating room, delivery room 


\section{$\underline{\text { ABSTRACT }}$}

\section{Background}

The exposure risks to front-line health care workers who are in close proximity for prolonged periods of time, caring for COVID-19 patients undergoing surgery or obstetrical delivery is unclear. Understanding of sample types that may harbour virus is important for evaluating risk.

Objectives

To determine if SARS-CoV-2 viral RNA from patients with COVID-19 undergoing surgery or obstetrical care is present in: 1) the peritoneal cavity of males and females 2) the female reproductive tract, 3) the environment of the surgery or delivery suite (surgical instruments, equipment used, air or floors) and 4) inside the masks of the attending health care workers.

\section{Methods}

The presence of SARS-CoV-2 viral RNA in patient, environmental and air samples was identified by real time reverse transcriptase polymerase chain reaction (RT-PCR). Air samples were collected using both active and passive sampling techniques.

\section{Results}

In this multi-centre observational case series, 32 patients with COVID-19 underwent urgent surgery or obstetrical delivery and 332 patient and environmental samples were collected and analyzed to determine if SARS-CoV-2 RNA was present. SARS-CoV-2 RNA was detected in: 4/24(16.7\%) patient samples, 5/60(8.3\%) floor, 1/54(1.9\%) air, 10/23(43.5\%) surgical instruments/equipment, 0/24 cautery filters and $0 / 143$ inner surface of mask samples.

\section{Conclusions}

While there is evidence of SARS-CoV-2 RNA in the surgical and obstetrical operative environment (6\% of samples taken), the finding of no detectable virus inside the masks worn by the medical teams would suggest a low risk of infection for our health care workers using appropriate personal protective equipment (PPE).

\section{MAIN TEXT}

\section{INTRODUCTION}

Front line health care providers are at risk of contracting infections when caring for patients with COVID$19^{1-3}$. Moreover, close, direct and often prolonged patient contact is essential in surgery and obstetrics. However, this may facilitate SARS-CoV-2 infections through the known vectors of respiratory droplets, 
aerosols and fomites, but infections may potentially be transmitted through exposure to the virus from the surgery or obstetrical delivery itself ${ }^{4-6}$. It remains unclear if the type of surgical/obstetrical procedure, may present different risks to HCWs attending these patients.

SARS-CoV-2, the virus that causes COVID-19 can spread via respiratory droplets and aerosols of infected persons through coughing, sneezing or talking ${ }^{7-10}$. Additionally, the virus has been documented to be present in the gastrointestinal (GI) tract and consequently any surgery that involves opening the GI tract (bowel related surgery) is thought to pose a risk to medical teams ${ }^{11,12}$. There are case reports of SARSCoV-2 virus detected in peritoneal fluid from a patient with COVID-19 undergoing surgery ${ }^{13,14}$. In the female reproductive tract, SARS-CoV-2 RNA has been identified in amniotic fluid, vaginal swabbing and documented cases of vertical transmission have been found ${ }^{15-18}$. Potentially, if the virus is present on peritoneal surfaces of males or females, in the female reproductive tract or the myometrium, this virus could be aerosolized via cautery smoke, or, from the release of $\mathrm{CO}_{2}$ gas from laparoscopic procedures. While there is no current published research on the presence of SARS-CoV-2 in the surgical smoke/ plume, there is existing literature which identified other viruses including human papillomavirus (HPV), Human Immunodeficiency Virus -1 and Hepatitis B virus in surgical smoke $\mathrm{e}^{19-28}$.

The risks of aerosolization from the respiratory tract is recognized ${ }^{29}$, but the risk of SARS-CoV-2 residing in the surgical site and the subsequent risk of aerosolizing this virus from the surgical site is not well studied. SARS-CoV-2 has been found in air samples with research demonstrating that the virus contained in aerosol particles can remain viable in the air for extended periods of time and are potentially infectious after both human shedding and airborne transport ${ }^{30,31}$. There is documentation of SARS-CoV-2 virus in the hospital ward setting ${ }^{6,32-34}$, in the delivery suite ${ }^{35}$ and with tracheostomies (an aerosol generating medical procedure $)^{29}$. 
More importantly, reports on the risks of SARS-CoV-2 viral contamination of the HCW in the operating room (OR) and birthing room setting (apart from studies on tracheostomies) were not identified by this author; although there have been studies reporting on HCW mask viral contamination in the patient ward setting ${ }^{36-39}$. Since a respiratory route is considered the main route of infection, knowledge of the risks of contamination of the masks is critical to assess the potential risks of viral exposure to the HCW working in the OR/delivery suites.

As COVID-19 is likely to continue to circulate and be endemic, even in the presence of vaccines, knowledge of risks will be essential to determine the optimal means to protect HCWs.

We seek to study the risk of contamination in the OR and birthing suite environment via evaluating the risk of aerosolization from the respiratory tract or from the surgical/obstetrical field during surgery or labor and delivery. This information is key to assessing the risks to HCWs who care for patients at the time of 1) vaginal delivery or cesarean section and 2) other surgical procedures whether they are vaginal, abdominal or laparoscopic. This knowledge would help guide best practice regarding the use of personal protective equipment (PPEs) and safety in the OR and birthing room.

The objectives of this study are to determine if SARS-CoV-2 viral RNA from patients with COVID-19 undergoing surgery or obstetrical care is present in: 1) the peritoneal cavity (males/females), 2) female reproductive tract, 3) on surgical instruments/equipment used, 4) the floor of the procedure rooms, 5) bioaerosols produced during surgery or obstetrical delivery, and 6) inside surgical masks of the attending health care workers.

\section{METHODS}


Study Design

From November 2020 to May 2021, patients with a nasopharyngeal (NP)/mid-turbinate (MT) swab positive for SARS-CoV-2 by RT-PCR (reverse transcriptase polymerase chain reaction), in need of urgent surgery or obstetrical delivery at one of two large academic Toronto hospitals: Sunnybrook Health Sciences Centre (Sunnybrook) or Sinai Health System, were prospectively identified by the surgical/obstetrical clinical teams. This study was approved by both hospitals' Research Ethics Boards. Environmental samples (air samples and floor samples) in the operating room or delivery suite were obtained with no patient or HCW consent required.

Following informed consent, patient samples (peritoneal fluid, vaginal, myometrial or placental swabs) were collected and following HCW consent, samples were obtained from their masks. Mask sampling was offered to any HCW in the room caring for the patient. Depending on the type of surgical case, patient consent was not possible, not always sought, or, not relevant to the study samples collected. Consenting HCWs agreed to follow up with hospital Occupational Health if SARS-CoV-2 RNA was detected on their mask.

Patient clinical and laboratory data were obtained by chart review and/or participant interview.

Eligibility:

Patients included those known to test positive by NP swab either symptomatic or asymptomatic within 30 days of diagnosis; or known symptomatic COVID-19 positive patients beyond 30 days of diagnosis.

HCWs included any consenting HCW present in the operating/delivery room, caring for the patient.

Study Samples (Appendix A included for detail): 
Patient sampling for any laparotomy cases included peritoneal cavity fluid (male or female). Patient samples for obstetrical cases included: vaginal fluid and swabs of the myometrium (at time of cesarean section) and membranous placenta.

Equipment and environmental samples included: swabs of the room floor (within 1 metre from the surgical site, and 2 metres away from the surgical site with a $10 \times 10 \mathrm{~cm}$ area for 17 cases, and a $30 \times 30 \mathrm{~cm}$ area for the final 13 cases $^{6}$; collection of the cautery filter; swab of equipment (e.g. endotracheal tube, saw blade, surgical instruments etc); and swab of the inside of the surgical mask worn by $\mathrm{HCWs}^{37,40,41}$. Swabbed samples were collected with either a sterile flocked swab or sterile dental pledget that was pre-moistened with universal transport media (UTM) and immediately placed in 3cc of UTM.

Bioaerosol sampling was obtained via two previously described methods: 1) Active air sampling via the GilAir Plus sampler was used at two locations: as close to the surgical site as possible (within 0.5-1 metres) and 2-3 metres away (Sensidyne ${ }^{\oplus}$, https://www.sensidyne.com/air-sampling-equipment/gilianair-sampling-pumps/gilair-plus/ $)^{42}$. Samples were collected with a $37 \mathrm{~mm}$ three-piece cassette with $0 \cdot 8$ $\mu \mathrm{m}$ polycarbonate filter, sampling at a rate of $3.5 \mathrm{~L} / \mathrm{min}$ for the duration of the procedure with PCR detection after elution from the filter 2) Passive air sampling was considered in the last 10 cases and involved an open Petri dish to collect any viral particles settling by gravity in the dish (within 1-2 metres of the patient) $)^{34,35,40,43,44}$.

Laboratory Methods:

All collected samples were processed at the Shared Hospital Laboratory (Sunnybrook). Aside from the cautery and active air sample filters, the lab staff were blinded to the source of the sample. 
Virus detection was performed by real-time RT-PCR using a multi-target assay currently utilized in the laboratory for detection of the virus ${ }^{45}$.

Additionally, the $\mathrm{Ct}$ (cycle threshold) value of the assay as an estimate of the viral load was used and where possible was obtained from the initial diagnostic swab of the patient.

The outcome of interest was SARS-CoV-2 RNA PCR positive samples. Whole genome sequencing was not performed with our surgical/obstetrical samples, but was performed on diagnostic nasopharyngeal swabs when possible, in order to identify variants of concern (VOC).

Sample Size: The primary outcome was the rate of SARS-CoV-2 RNA PCR positive samples from the HCWs masks. The expected outcome was $0 \%$ positivity. We planned to study 40 patients with an expected mean of 2-3 HCW masks per patient (or 100 mask samples) which, with an expected positive rate of $0 \%$, would provide a $95 \%$ confidence interval range of $0-5 \%$ ( $R$ Statistical Software: $R$ version 3.5.3, 2019). The study was closed after sampling from 32 patients, with the collection of 143 masks which provided adequate data to study the primary outcome. An interim analysis after the first 20 patients recruited was performed and based upon new published studies, a decision was made to add passive air sampling to the protocol ${ }^{34,35,40,43}$.

Descriptive statistics, Shapiro-Wilk normality test, Mann-Whitney $U$ test and 2-sample test for equality of proportions with continuity correction tests were used where appropriate (R Statistical Software: R version 3.5.3, 2019).

\section{RESULTS}


Patients:

A total of 32 patients with COVID-19 (Table I), 18 female and 14 male were enrolled (mean 53.55 years, $S D=18.068$, range: $20-88$ years): 9 obstetrical patients ( 5 cesarean sections, 4 vaginal births) from Sunnybrook and Sinai Health System, and 23 semi/urgent surgical patients from Sunnybrook's Divisions of General Surgery (7/23), Trauma/Orthopedic Surgery (7/23), Gynecologic Oncology (2/23), Burn (2/23), Plastic Surgery (1/23), Cardiac Surgery (1/23), Vascular Surgery (1/23), Gastroenterology (1/23) and Neurosurgery $(1 / 23)$.

Of the 32 patients enrolled, the patient's first SARS-CoV-2 positive nasopharyngeal swab occurred a median of 4 days before their procedure (mean 13.77, range: 0-70 days). 11/32 patients had a repeat NP swab closer to the date of their procedure (median 3 days, mean 5.08, range: 0-24 days).

Samples tested:

A total of 343 samples were taken for SARS-CoV-2 RNA detection: 11/343 were duplications (1 patient submitted 2 masks; 10/12 endotracheal tubes were sampled twice with different methodology: flocked swab (4/12 samples positive for viral RNA) and dental pledget (7/10 samples positive). Twenty of the $332(6.02 \%)$ samples tested positive for SARS-CoV-2 RNA (Table II): 8/12 endotracheal tubes (3/10 tested positive with both flocked swab and dental pledget), $1 / 6$ peritoneal fluid ( $1 / 5$ cesarean section cases, 0/1 trauma laparotomy case) , 1/7 placentas, 1/4 myometrial swabs, 1/7 vaginal fluid, 2/11 samples from surgical equipment of 11 different surgical cases (positives found from the scissors and clamps from an abdominal hysterectomy and from the gastroscope used intra-operatively for a gastroduodenoscopy), $1 / 7$ passive air samples, and $5 / 60$ floor samples $(5 / 24$ of the $30 \times 30 \mathrm{~cm}$ samples and $0 / 36$ of the $10 \times 10 \mathrm{~cm}$ samples were positive for SARS-CoV-2 RNA: 4/30 samples taken 1 metre and 1/30 samples taken 2 metres from the surgical field were positive). There were no positive samples for 
SARS-CoV-2 RNA from among cautery filters (0/24 cases); active air sampling (0/47, 25 cases) and the inside of HCWs masks (0/143, 32 cases sampled). 0/2 patient masks sampled were positive.

In 5 surgical cases, the initial positive diagnostic test was beyond 30 days: 1 cesarean section (30 days) and 4 tracheostomies $(50,54,62$ and 70 days). Four of 5 of these cases (30,54, 62, and 70 days) had positive endotracheal tube samples, and 2 of the 4 endotracheal tube positive cases had positive floor samples (54 and 62 days since diagnosis of COVID-19).

Variants of concern (VOC) were identified in 10 cases. Of the 10 VOC cases: 9 were the Alpha variant (United Kingdom/B.1.1.7), and 1 was either Beta or Gamma variant (South African/B.1.351 or Brazilian/P.1). Of the 10 VOC cases, the following sites tested SARS-CoV-2 RNA positive: 3/4 endotracheal tubes (75\%), 2/18 floor samples (including one sample 2 metres away), 1/5 passive air samples, 2/6 cases where the surgical instruments were tested. In addition, the positive peritoneal fluid, myometrial swab and vaginal fluid swab samples came from the same patient who tested positive for the Alpha VOC. There was no significant difference between the proportion of positive samples when comparing the VOC group ( $n=10)$ versus unknown/not VOC group $(n=22)$.

The cycle threshold $(\mathrm{Ct})$ value of the initial NP swab positive for SARS-CoV-2 RNA was recorded for 20/32 patients (median: 30.3 , mean: 26.65, range: $11.86-37.25$ ). For the VOC group, $9 / 10$ had Ct values recorded (median: 24.41, mean: 24.52 [95\% Cl: 18.72-30.99], range: 11.86-37.25). For the group that is unknown/not VOC, 11/22 have Ct values recorded (median: 31.10, mean: 28.41 [Cl: 25.35-30.33], range: 13.45-35.29). There was no significant difference in Ct values between these two groups (MannWhitney $\mathrm{U}$ test, $\mathrm{p}=0.4561$ ). The Ct values of the initial NP swabs were significantly lower (indicating higher viral loads) in those tested who were subsequently found to have any study sample with SARS- 
CoV-2 RNA (13/32: Ct recorded in 8/13) versus those without any positive study samples (19/32: Ct recorded in 12/19) with a mean Ct 21.72: $95 \% \mathrm{Cl} 16.90-27.29$ vs mean 29.96: 95\% Cl 27.07-33.43 respectively (Mann-Whitney $U$ test, $p=0.007$ ).

\section{DISCUSSION}

Several studies have documented potential risks of SARS-CoV-2 infection to HCWs in the clinic or hospital ward settings ${ }^{1,6,29,46}$. To our knowledge, this is the first study evaluating potential exposure risks to HCWs in the operating room with a variety of surgical procedures. The $\mathrm{OR}$ is a unique environment as HCWs are in prolonged and very close contact (hands on) with patients. In our study, we detected SARSCoV-2 RNA in non-respiratory patient samples (peritoneal fluid, vaginal fluid, myometrium, placenta), surgical equipment/instruments (endotracheal tubes, gastroscope, laparotomy surgical clamps \& scissors), and the surgical room environment (floor, air); but no contamination of the surgical masks worn by HCWs was detected.

Our study corroborates earlier studies that have shown evidence of virus in the respiratory tract and in some of the surgical/obstetrical fields ${ }^{12,13,15-18,47-49}$. We have documented evidence of SARS-CoV-2 RNA in the GI tract, peritoneal cavity, and female genital tract, all of which could potentially be sources of aerosolized virus/viral particles. We did not find evidence of viral RNA in the orthopedic equipment sampled (e.g. saw blade and drill bits), retractors used in cardiac/thoracic surgery and the dermatome used in burn surgery. This may indicate that SARS-CoV-2 does not reside in this type of tissue or at least not present with a viral load high enough for detection.

With our study and others reporting the finding of virus in the peritoneal cavity laparoscopy (and its positive insufflation pressure) theoretically may be considered an aerosol generating procedure justifying the use of appropriate PPE and best practice measures ${ }^{11,13,14,50-54}$. 
We used standard techniques for air and floor sampling and found evidence of aerosolization of SARS-

CoV-2 $2^{6,34,35,40,42}$. While the frequency of positive tests was low, this does indicate that aerosolization of the virus does occur in surgery. It is possible that the true positive rates are higher since there are known limitations with the sampling and testing techniques used in this study $6,34,35,40,42$.

We looked for characteristics of the patients' infections that would increase the risks of detection of viral RNA in the surgical/obstetrical fields or local environment. Higher viral load detected on the initial NP swab (as estimated by the Ct threshold) was associated with a higher risk of detectable virus in our samples, while the subtype of the SARS-CoV-2 virus was not (although the numbers were insufficient for sub-analysis on viral subtyping).

This study was not able to determine if the origin of aerosolized/droplet virus is arising from the surgical fields in the smoke plume. Others did not detect SARS-CoV-2 in electrocautery smoke despite using high viral loads in an in vitro setting ${ }^{28}$. While the lack of any positive viral RNA found on the smoke evacuator filters tested would indicate that the viral contamination from the surgical field is absent or below detection limits, these results cannot be used to definitely conclude that surgical smoke does not harbour SARS-CoV-2.

Since infection with SARS-CoV-2 is primarily via the respiratory tract, we chose to sample the inside of HCWs masks as a means of identifying viral contamination in close proximity to the HCWs respiratory tract. Face mask sampling has previously been shown to be an efficacious way of detecting Mycobacterium tuberculosis contamination ${ }^{55}$ and has been used to detect SARS-CoV-2 contamination of masks worn by HCW exposed to COVID-19 infected patients on wards (0/25 positive, inside surface) and directly from patient masks (6/10 positive) ${ }^{37}$. Others have studied SARS-CoV-2 viral contamination on the outer surface of face shields worn by HCWs attending women with COVID-19 in labor (one vaginal delivery with all face shields tested being positive $)^{35}$. We sampled the inside of masks and found 0/143 
medRxiv preprint doi: https://doi.org/10.1101/2021.09.03.21262874; this version posted September 7, 2021. The copyright holder for this preprint

(which was not certified by peer review) is the author/funder, who has granted medRxiv a license to display the preprint in perpetuity.

It is made available under a CC-BY-NC-ND 4.0 International license .

HCWs masks and 0/4 HCWs' face shields to be positive for SARS-CoV-2 RNA. Our study did not detect

SARS-CoV-2 RNA on the inner surface of any mask used by HCWs. This is reassuring, since this finding indicates a low risk of HCWs involved with surgery or obstetrical care being exposed to SARS-CoV-2 RNA if using appropriate PPE.

Limitations:

Our study did not include data on the involved HCWs to determine information regarding previous infections or vaccinations, or if they developed subsequent COVID-19 infections.

Detection of SARS-CoV-2 RNA in bioaerosols is recognized to be challenging, being highly dependent upon air flow, exchange rates and source of emissions (reviewed by Borges et al) and it is suggested that parallel sampling with more than one technique may increase sensitivity ${ }^{56}$. Thus, we employed two air sampling techniques, active air sampling used previously by two of our coauthors (finding 3/146 positive air samples taken from patient rooms $)^{42}$ and the passive technique similar to what is described by others for SARS-CoV-2 virus $34,35,40,43$.

Despite these efforts, we recognize that it is likely that not all viral contamination was detected with this study. Further, even though viral RNA was detected in some samples, this study did not determine if infectious virus was present.

\section{CONCLUSION}

There is evidence of SARS-CoV-2 RNA in the surgical and obstetrical patient's operative environment (surgical surfaces and aerosolized). However, the finding of no detectable virus on the inner surface of masks worn by the health care teams reassuringly suggests a low risk of infection when wearing appropriate personal protective equipment. 


\section{ACKNOWLEDGEMENTS}

We are grateful to our operating room nurses and our obstetrical nurses who participated in this study as well as the patients, their anesthetists and their surgeons.

\section{Conflict of Interest Statement}

No disclosures or conflicts of interest relevant to the subject of this manuscript are reported.

\section{Funding sources}

This study was supported by the Innovation Fund of the Alternative Funding Plan for the Academic Health Sciences Centres of Ontario (Lee) and a Chair's summer research student grant from the Department of Obstetrics \& Gynecology, University of Toronto (Perruzza).

\section{Role of the Funder/Sponsor:}

The funders had no role in the design and conduct of the study; collection, management, analysis and interpretation of the data; preparation, review, or approval of the manuscript; and decision to submit the manuscript for publication.

\section{REFERENCES}

1. Wang D, Hu B, Hu C, et al. Clinical Characteristics of 138 Hospitalized Patients With 2019 Novel Coronavirus-Infected Pneumonia in Wuhan, China. JAMA. 2020.

2. Baker MG, Peckham TK, Seixas NS. Estimating the burden of United States workers exposed to infection or disease: A key factor in containing risk of COVID-19 infection. PLoS One. 2020;15(4):e0232452.

3. Shah ASV, Wood R, Gribben C, et al. Risk of hospital admission with coronavirus disease 2019 in healthcare workers and their households: nationwide linkage cohort study. BMJ. 2020;371:m3582.

4. $\quad$ ASRM COVID task force: Segars JK, Q.;McQueen, D. B.;Kotlyar, A.;Glenn, T.;Knight, Z.;Feinberg, E. C.;Taylor, H. S.;Toner, J. S.;Kawwass, J. F. Prior and Novel Coronaviruses, COVID-19, and Human Reproduction: What Is Known? Fertility and Sterility. 2020.

5. van Doremalen NM, D. H.;Holbrook, M. G.;Gamble, A.;Williamson, B.;Tamin, A.;Harcourt, J. L.;Thornburg, N. J.;Gerber, S. I.;Lloyd-Smith, J. O.;de Wit, E.;Munster, V. J.;. Aerosol and Surface Stability of SARS-CoV-2 as Compared with SARS-CoV-1. N Engl J Med 2020;382:1564-1567.

6. Santarpia JL, Rivera DN, Herrera VL, et al. Aerosol and surface contamination of SARS-CoV-2 observed in quarantine and isolation care. Sci Rep. 2020;10(1):12732. 
7. CDC. Coronavirus Disease (COVID-19). 2021; https://www.cdc.gov/dotw/covid-19/index.html. Accessed August 30, 2021.

8. Wiersinga WJ, Rhodes A, Cheng AC, Peacock SJ, Prescott HC. Pathophysiology, Transmission, Diagnosis, and Treatment of Coronavirus Disease 2019 (COVID-19): A Review. JAMA. 2020;324(8):782-793.

9. Karia R, Gupta I, Khandait H, Yadav A, Yadav A. COVID-19 and its Modes of Transmission. SN Compr Clin Med. 2020:1-4.

10. Kutti-Sridharan G, Vegunta R, Vegunta R, Mohan BP, Rokkam VRP. SARS-CoV2 in Different Body Fluids, Risks of Transmission, and Preventing COVID-19: A Comprehensive Evidence-Based Review. Int J Prev Med. 2020;11:97.

11. Surgeons SoAGaE. Update to SAGES recommendations regarding surgical response to COVID-19 crisis. 2020 March 21; https://www.sages.org/recommendations-surgical-response-covid-19/. Accessed August 30, 2021.

12. Gu J, Han B, Wang J. COVID-19: Gastrointestinal Manifestations and Potential Fecal-Oral Transmission. Gastroenterology. 2020;158(6):1518-1519.

13. Coccolini F, Tartaglia D, Puglisi A, et al. SARS-CoV-2 Is Present in Peritoneal Fluid in COVID-19 Patients. Ann Surg. 2020;272(3):e240-e242.

14. Barberis A, Rutigliani M, Belli F, Ciferri E, Mori M, Filauro M. SARS-Cov-2 in peritoneal fluid: an important finding in the Covid-19 pandemic. Br J Surg. 2020.

15. Schwartz A, Yogev $Y$, Zilberman A, et al. Detection of severe acute respiratory syndrome coronavirus 2 (SARS-CoV-2) in vaginal swabs of women with acute SARS-CoV-2 infection: a prospective study. BJOG. 2021;128(1):97-100.

16. Barber E, Kovo M, Leytes S, et al. Evaluation of SARS-CoV-2 in the Vaginal Secretions of Women with COVID-19: A Prospective Study. J Clin Med. 2021;10(12).

17. Vivanti AJ, Vauloup-Fellous C, Prevot S, et al. Transplacental transmission of SARS-CoV-2 infection. Nat Commun. 2020;11(1):3572.

18. Deniz M, Tezer H. Vertical transmission of SARS CoV-2: a systematic review. The Journal of Maternal-Fetal \& Neonatal Medicine. 2020:1-8.

19. Sawchuk WS, Weber PJ, Lowy DR, Dzubow LM. Infectious papillomavirus in the vapor of warts treated with carbon dioxide laser or electrocoagulation: detection and protection. J Am Acad Dermatol. 1989;21(1):41-49.

20. Gloster HM, Jr., Roenigk RK. Risk of acquiring human papillomavirus from the plume produced by the carbon dioxide laser in the treatment of warts. J Am Acad Dermatol. 1995;32(3):436-441.

21. Johnson GK, Robinson WS. Human immunodeficiency virus-1 (HIV-1) in the vapors of surgical power instruments. J Med Virol. 1991;33(1):47-50.

22. Baggish MS, Poiesz BJ, Joret D, Williamson P, Refai A. Presence of human immunodeficiency virus DNA in laser smoke. Lasers Surg Med. 1991;11(3):197-203.

23. Kwak HD, Kim SH, Seo YS, Song KJ. Detecting hepatitis B virus in surgical smoke emitted during laparoscopic surgery. Occup Environ Med. 2016;73(12):857-863.

24. Hallmo $P$, Naess O. Laryngeal papillomatosis with human papillomavirus DNA contracted by a laser surgeon. Eur Arch Otorhinolaryngol. 1991;248(7):425-427.

25. Calero LB, T. Laryngeal papillomatosis - first recognition in Germany as an occupational disease in an operating room nurse. Laryngorhinootologie. 2003;82(11):790-793.

26. Rioux M, Garland A, Webster D, Reardon E. HPV positive tonsillar cancer in two laser surgeons: case reports. J Otolaryngol Head Neck Surg. 2013;42:54.

27. Zakka K, Erridge S, Chidambaram S, et al. Electrocautery, Diathermy, and Surgical Energy Devices: Are Surgical Teams at Risk During the COVID-19 Pandemic? Ann Surg. 2020;272(3):e257-e262. 
28. Sowerby L, Nichols AC, Gibson R, et al. Assessing the Risk of SARS-CoV-2 Transmission via Surgical Electrocautery Plume. JAMA Surg. 2021.

29. Staibano P, Levin M, McHugh T, Gupta M, Sommer DD. Association of Tracheostomy With Outcomes in Patients With COVID-19 and SARS-CoV-2 Transmission Among Health Care Professionals: A Systematic Review and Meta-analysis. JAMA Otolaryngol Head Neck Surg. 2021.

30. Guzman MI. An overview of the effect of bioaerosol size in coronavirus disease 2019 transmission. Int J Health Plann Manage. 2021;36(2):257-266.

31. Fears ACK, W.B.;Duprex, P.;Hartman, A.;Weaver, S.C.;Plante, K.C.;Mirchandani, D.;Plante, J.A.;Aguilar, P.V.;Fernández, D.;Nalca A.;Totura, A.;Dyer, D.;Kearney, B.;Lackemeyer, M.;Bohannon, J.K.;Johnson, R.;Garry,R.F.;Reed, D.S.;Roy C.J. . Comparative dynamic aerosol efficiencies of three emergent coronaviruses and the unusual persistence of SARS-CoV-2 in aerosol suspensions. medRxiv. 2020.

32. Chia PY, Coleman KK, Tan YK, et al. Detection of air and surface contamination by SARS-CoV-2 in hospital rooms of infected patients. Nat Commun. 2020;11(1):2800.

33. Ong SWX, Tan YK, Chia PY, et al. Air, Surface Environmental, and Personal Protective Equipment Contamination by Severe Acute Respiratory Syndrome Coronavirus 2 (SARS-CoV-2) From a Symptomatic Patient. JAMA. 2020.

34. Nissen K, Krambrich J, Akaberi D, et al. Long-distance airborne dispersal of SARS-CoV-2 in COVID19 wards. Sci Rep. 2020;10(1):19589.

35. Hermesch AC, Horve PF, Edelman A, et al. Severe Acute Respiratory Syndrome Coronavirus 2 (SARS-CoV-2) Environmental Contamination and Childbirth. Obstet Gynecol. 2020;136(4):827829.

36. Hirota K. Air contamination with SARS-CoV-2 in the operating room. J Anesth. 2021;35(3):333336.

37. Dargahi A, Jeddi F, Ghobadi $\mathrm{H}$, et al. Evaluation of masks' internal and external surfaces used by health care workers and patients in coronavirus-2 (SARS-CoV-2) wards. Environ Res. 2021;196:110948.

38. Chughtai AA, Stelzer-Braid S, Rawlinson W, et al. Contamination by respiratory viruses on outer surface of medical masks used by hospital healthcare workers. BMC Infect Dis. 2019;19(1):491.

39. Jones $\mathrm{P}$, Roberts $\mathrm{S}$, Hotu $\mathrm{C}$, Kamona $\mathrm{S}$. What proportion of healthcare worker masks carry virus? A systematic review. Emerg Med Australas. 2020;32(5):823-829.

40. Kim MC, Bae S, Kim JY, et al. Effectiveness of surgical, KF94, and N95 respirator masks in blocking SARS-CoV-2: a controlled comparison in 7 patients. Infect Dis (Lond). 2020;52(12):908912.

41. Phan LT, Sweeney D, Maita $D$, et al. Respiratory viruses on personal protective equipment and bodies of healthcare workers. Infect Control Hosp Epidemiol. 2019;40(12):1356-1360.

42. Kotwa JDJ, A.J.; Mbareche H.; Yip, L.; Aftanas, P; Barati, S.; Bell, N.G.; Bryce, E.; Coomes, E.; Crowl, G.; Duchaine, C.; Faheem, A.; Farooqi, L.; Hiebert, R.; Katz, K.; Khan, S.; Kozak, R.; Li, A.X.; Mistry, H.P.; Mozafarihashjin, M.; Nasir, J.A.; Nirmalarajah, K.; Panousis, E.M.; Paterson, A.; Plenderleith, S.; Powis, J.; Prost, K.; Schryer, R; Taylor, M.; Veillette, M.; Wong, T.; Zhong, X.Z.; McArthur, A.G.; McGeer, A.J.; Mubareka, S. Surface and air contamination with SARS-CoV-2 from hospitalized COVID-19 patients in Toronto, Canada. medRxiv. 2021.

43. Baboli Z, Neisi N, Babaei AA, et al. On the airborne transmission of SARS-CoV-2 and relationship with indoor conditions at a hospital. Atmos Environ (1994). 2021;261:118563.

44. Napoli C, Marcotrigiano V, Montagna MT. Air sampling procedures to evaluate microbial contamination: a comparison between active and passive methods in operating theatres. $B M C$ Public Health. 2012;12:594. 
45. Vermeiren C, Marchand-Senecal X, Sheldrake E, et al. Comparison of Copan Eswab and FLOQswab for COVID-19 PCR diagnosis: working around a supply shortage. J Clin Microbiol. 2020.

46. Guo ZD, Wang ZY, Zhang SF, et al. Aerosol and Surface Distribution of Severe Acute Respiratory Syndrome Coronavirus 2 in Hospital Wards, Wuhan, China, 2020. Emerg Infect Dis. 2020;26(7).

47. Wang W, Xu Y, Gao R, et al. Detection of SARS-CoV-2 in Different Types of Clinical Specimens. JAMA. 2020.

48. Zou L, Ruan F, Huang M, et al. SARS-CoV-2 Viral Load in Upper Respiratory Specimens of Infected Patients. N Engl J Med. 2020;382(12):1177-1179.

49. Roberts DJ EA, Romero RJ, Coyne CB, Ting DT, Hornick JL, Zaki SR, Adhikari UD, Serghides L, Gaw SL, Metz TD, on behalf of all members of the NIH/NICHD SARSCoV-2 Placental Infection Workshop. SPECIAL REPORT: A standardized definition of placental infection by severe acute respiratory syndrome coronavirus 2 (SARS-CoV-2), a consensus statement from the National Institutes of Health/Eunice Kennedy Shriver National Institute of Child Health and Human Development (NIH/NICHD) SARS-CoV-2 placental infection workshop. American Journal of Obstetrics and Gynecology. 2021.

50. Pavan N, Crestani A, Abrate A, et al. Risk of Virus Contamination Through Surgical Smoke During Minimally Invasive Surgery: A Systematic Review of the Literature on a Neglected Issue Revived in the COVID-19 Pandemic Era. Eur Urol Focus. 2020;6(5):1058-1069.

51. Laparoscopists AAoG. Statement regarding Laparoscopic Surgery During the COVID-19 Pandemic 2020 https://www.aagl.org/news/covid-19-joint-statement-on-minimally-invasive-gynecologicsurgery/. Accessed August 30, 2021.

52. Mottrie A. ERUS (EAU Robotic Urology Section) guidelines during COVID-19 emergency. 2020.

53. Surgeons ACo. COVID-19: Considerations for Optimum Surgeon Protection Before, During, and After Operation. 2020; https://www.facs.org/covid-19/clinical-guidance/surgeon-protection; https://www.facs.org/covid-19/faqs. Accessed August 30, 2021.

54. Surgeons CAoG. Statement from the CAGS MIS Committee re: Laparoscopy and the risk of aerosolization. 2020; https://cags-accg.ca/wp-content/uploads/2020/03/Laparoscopy-and-therisk-of-aerosolization.pdf. Accessed August 30, 2021.

55. Williams CM, Abdulwhhab M, Birring SS, et al. Exhaled Mycobacterium tuberculosis output and detection of subclinical disease by face-mask sampling: prospective observational studies. Lancet Infect Dis. 2020;20(5):607-617.

56. Borges JT, Nakada LYK, Maniero MG, Guimaraes JR. SARS-CoV-2: a systematic review of indoor air sampling for virus detection. Environ Sci Pollut Res Int. 2021. 
Table 1: Patient and case characteristics with results of samples taken

\begin{tabular}{|c|c|c|c|c|c|c|c|c|c|c|c|}
\hline $\begin{array}{l}\text { ID } \\
\#\end{array}$ & $\begin{array}{l}\text { Age } \\
\text { range } \\
\text { (yrs) }\end{array}$ & Sex & $\begin{array}{l}\text { No. days } \\
\text { from } 1^{\text {st }} \\
\text { COVID-19 } \\
\text { positive } \\
\text { test to } \\
\text { surgery } \\
\text { (repeat } \\
\text { test) }\end{array}$ & $\begin{array}{l}\text { Surgical } \\
\text { Division }\end{array}$ & Procedure performed & VOC & $\begin{array}{l}\text { NP swab } \\
\text { (Ct value) } \\
\text { a, b }\end{array}$ & $\begin{array}{l}\text { Positive }^{c} \\
\text { samples } \\
\text { obtained } \\
\text { (Ct value) }\end{array}$ & $\begin{array}{l}\text { Active air } \\
\text { sampling } \\
\text { time } \\
\text { (min) }\end{array}$ & Negative $^{d}$ samples & $\begin{array}{l}\text { No. } \\
\text { negative } \\
\text { HCW } \\
\text { masks }\end{array}$ \\
\hline 1 & $30-39$ & $\mathrm{~F}$ & 3 & $\mathrm{OB}$ & $\begin{array}{l}\text { Caesarean section } \\
\text { (spinal anesthesia) }\end{array}$ & $\begin{array}{l}\text { Not } \\
\text { tested }\end{array}$ & $-(n / a)$ & - (none) & 74 & $\begin{array}{l}\text { - peritoneal fluid, } \\
\text { placenta, } \\
\text { myometrium, } \\
\text {-floor }\end{array}$ & 3 \\
\hline 2 & $30-39$ & $\mathrm{~F}$ & 4 & $\mathrm{OB}$ & $\begin{array}{l}\text { Caesarean section } \\
\text { (spinal anesthesia) }\end{array}$ & $\begin{array}{l}\text { Not } \\
\text { tested }\end{array}$ & - & - & 137 & $\begin{array}{l}\text {-peritoneal fluid, } \\
\text { placenta, } \\
\text { myometrium, } \\
\text {-floor }\end{array}$ & 3 \\
\hline 3 & $40-49$ & $\mathrm{~F}$ & 3 & $\mathrm{OB}$ & $\begin{array}{l}\text { Caesarean section } \\
\text { (spinal anesthesia) }\end{array}$ & $\begin{array}{l}\text { Not } \\
\text { tested }\end{array}$ & 30.89 & $\begin{array}{l}\bullet \text { placenta } \\
(25.9)\end{array}$ & 89 & $\begin{array}{l}\text {-vaginal fluid } \\
\text { - patient mask } \\
\text { - floor }\end{array}$ & 5 \\
\hline 4 & $20-29$ & $\mathrm{~F}$ & $30(24)$ & OB & $\begin{array}{l}\text { Caesarean section } \\
\text { (intubation and } \\
\text { extubation) }\end{array}$ & Alpha & 18.69 & $\begin{array}{l}\bullet \mathrm{ETT} \\
(25.66)\end{array}$ & 125 & $\begin{array}{l}\text { •peritoneal fluid, } \\
\text { placenta, } \\
\text { myometrium, } \\
\text {-floor }\end{array}$ & 6 \\
\hline 5 & $20-29$ & $\mathrm{~F}$ & $14(0)$ & $\mathrm{OB}$ & $\begin{array}{l}\text { Caesarean section } \\
\text { (spinal anesthesia) }\end{array}$ & Not VOC & 34.29 & - & $\begin{array}{c}\text { Not } \\
\text { sampled }\end{array}$ & $\begin{array}{l}\text {-peritoneal fluid, } \\
\text { placenta }\end{array}$ & 4 \\
\hline 6 & $30-39$ & $\mathrm{~F}$ & 3 & OB & Caesarean section & Alpha & 24.41 & $\begin{array}{l}\cdot \text { Vaginal } \\
\text { fluid } \\
(23.45) \\
\bullet \text { Peritoneal } \\
\text { fluid (25.1) } \\
\bullet \text { myometri } \\
\text { um (28.34) }\end{array}$ & $\begin{array}{c}\text { Not } \\
\text { sampled }\end{array}$ & •floor & 3 \\
\hline 7 & $30-39$ & $\mathrm{~F}$ & 1 & OB & Vaginal delivery & $\begin{array}{l}\text { Not } \\
\text { tested }\end{array}$ & 31.31 & - & $\begin{array}{c}\text { Not } \\
\text { sampled }\end{array}$ & $\begin{array}{l}\text { - vaginal fluid } \\
\text { - patient mask } \\
\text { - floor }\end{array}$ & 3 \\
\hline 8 & $30-39$ & $\mathrm{~F}$ & 0 & $\mathrm{OB}$ & Vaginal delivery & $\begin{array}{l}\text { Not } \\
\text { tested }\end{array}$ & 18.87 & - & $\begin{array}{c}\text { Not } \\
\text { sampled }\end{array}$ & $\begin{array}{l}\text { •vaginal fluid, } \\
\text { placenta, } \\
\text { •floor }\end{array}$ & 1 \\
\hline
\end{tabular}




\begin{tabular}{|c|c|c|c|c|c|c|c|c|c|c|c|}
\hline 9 & $30-39$ & $F$ & $14(0)$ & OB & $\begin{array}{l}\text { Vaginal (vacuum) } \\
\text { Delivery }\end{array}$ & Alpha & 14.81 & - & $\begin{array}{c}\text { Not } \\
\text { sampled }\end{array}$ & $\begin{array}{l}\text { - vaginal fluid } \\
\text { - placenta } \\
\text {-integrated visor of } \\
\text { mask (obstetrician) }\end{array}$ & 6 \\
\hline 10 & $50-59$ & $\mathrm{~F}$ & 1 & $\begin{array}{l}\text { Gyne } \\
\text { Oncology }\end{array}$ & $\begin{array}{l}\text { TAH BSO, node } \\
\text { dissection } \\
\text { (intubation and } \\
\text { extubation) }\end{array}$ & $\begin{array}{l}\text { Not } \\
\text { tested }\end{array}$ & 32.17 & - & 146 & $\begin{array}{l}\bullet \text { ETT } \\
\bullet \text { floor }\end{array}$ & 5 \\
\hline 11 & $40-49$ & $\mathrm{~F}$ & 16 & $\begin{array}{l}\text { Gyne } \\
\text { Oncology }\end{array}$ & $\begin{array}{l}\text { TAHBSO omentectomy } \\
\text { (intubation and } \\
\text { extubation) }\end{array}$ & Alpha & 11.86 & $\begin{array}{l}\bullet \text { ETT } \\
(25.37) \\
\bullet \text { surgical } \\
\text { clamps, } \\
\text { scissors } \\
(27.13) \\
\text { •floor at 2- } \\
\text { metres } \\
(28.94)\end{array}$ & 149 & $\begin{array}{l}\text {-floor near the OR } \\
\text { table }\end{array}$ & 6 \\
\hline 12 & $80-89$ & $\mathrm{~F}$ & 4 & Ortho & $\begin{array}{l}\text { L hip hemiarthroplasty } \\
\text { (spinal anesthesia) }\end{array}$ & $\begin{array}{l}\text { Not } \\
\text { tested }\end{array}$ & 21.44 & - & $\begin{array}{c}\text { Not } \\
\text { sampled }\end{array}$ & $\begin{array}{l}\text { - saw blade } \\
\text {-floor }\end{array}$ & 1 \\
\hline 13 & $30-39$ & $\mathrm{~F}$ & 2 & Ortho & $\begin{array}{l}\text { Bilat tibial fracture } \\
\text { (spinal anesthesia) }\end{array}$ & $\begin{array}{l}\text { Not } \\
\text { tested }\end{array}$ & - & - & 176 & $\begin{array}{l}\text {-drill bit } \\
\text {-floor }\end{array}$ & 5 \\
\hline 14 & $50-59$ & $M$ & $22(3)$ & Ortho & $\begin{array}{l}\text { T10-T12 spinal } \\
\text { decompression } \\
\text { (arrived in OR } \\
\text { intubated and left } \\
\text { intubated) }\end{array}$ & $\begin{array}{l}\text { Not } \\
\text { tested }\end{array}$ & 29.17 & $\begin{array}{l}\text { ETT } \\
(22.27)\end{array}$ & 242 & -floor & 6 \\
\hline 15 & $70-79$ & $M$ & $2(0)$ & Ortho & $\begin{array}{l}\text { ORIF cervical spine } \\
\text { fracture } \\
\text { (arrived in OR } \\
\text { intubated and left } \\
\text { intubated) }\end{array}$ & $\begin{array}{l}\text { Not } \\
\text { tested }\end{array}$ & - & - & 211 & $\begin{array}{l}\text {-Petri dish } \\
\text {-floor }\end{array}$ & 5 \\
\hline 16 & $60-69$ & $\mathrm{~F}$ & $4(2)$ & Ortho & ORIF ankle, fibula & Alpha & 32.35 & - & 106 & $\begin{array}{l}\text { - scalpel blade and } \\
\text { clamps } \\
\text {-Petri dish } \\
\text {-floor }\end{array}$ & 5 \\
\hline 17 & $50-59$ & $M$ & 2 & Ortho & $\begin{array}{l}\text { Humerus fracture } \\
\text { (came to OR intubated } \\
\text { and left OR intubated) }\end{array}$ & Not VOC & 13.45 & $\begin{array}{l}\text { •floor } \\
(21.97)\end{array}$ & 97 & $\begin{array}{l}\text { - scissors and } \\
\text { clamps } \\
\text {-Petri dish }\end{array}$ & 5 \\
\hline
\end{tabular}




\begin{tabular}{|c|c|c|c|c|c|c|c|c|c|c|c|}
\hline 18 & $70-79$ & $M$ & $26(5)$ & Ortho & $\begin{array}{l}\text { Superficial and deep } \\
\text { compartment } \\
\text { irrigation of leg and } \\
\text { debridement } \\
\text { (arrived in OR } \\
\text { intubated and left OR } \\
\text { intubated) }\end{array}$ & Alpha & 37.25 & - & 68 & $\begin{array}{l}\text { - scalpel blade, } \\
\text { scissors and clamps } \\
\text {-Petri dish } \\
\text {-floor }\end{array}$ & 4 \\
\hline 19 & $50-59$ & $M$ & 1 & $\begin{array}{l}\text { General } \\
\text { Surgery }\end{array}$ & $\begin{array}{l}\text { Laparotomy (came to } \\
\text { OR intubated and left } \\
\text { intubated) }\end{array}$ & $\begin{array}{l}\text { Not } \\
\text { tested }\end{array}$ & 32.7 & - & 189 & $\begin{array}{l}\text { - Peritoneal fluid, } \\
\text { - floor } \\
\text {-face shield } \\
\text { (surgeon) }\end{array}$ & 4 \\
\hline 20 & $50-59$ & $\mathrm{~F}$ & 15 & $\begin{array}{l}\text { General } \\
\text { Surgery }\end{array}$ & $\begin{array}{l}\text { Bilat mastectomy } \\
\text { (intubation and } \\
\text { extubation) }\end{array}$ & $\begin{array}{l}\text { Not } \\
\text { tested }\end{array}$ & - & - & 123 & $\begin{array}{l}\bullet \text { ETT } \\
\bullet \text { floor }\end{array}$ & 5 \\
\hline 21 & $70-79$ & $M$ & $70(3)$ & $\begin{array}{l}\text { General } \\
\text { Surgery }\end{array}$ & Tracheostomy & $\begin{array}{l}\text { Not } \\
\text { tested }\end{array}$ & - & $\begin{array}{l}\cdot \operatorname{ETT} \\
(21.74)\end{array}$ & 111 & •floor & 5 \\
\hline 22 & $60-69$ & $M$ & $50(5)$ & $\begin{array}{l}\text { General } \\
\text { Surgery }\end{array}$ & Tracheostomy & Alpha & - & - & 69 & $\begin{array}{l}\text { •ETT } \\
\bullet \text { floor }\end{array}$ & 5 \\
\hline 23 & $60-69$ & $M$ & $54(16)$ & $\begin{array}{l}\text { General } \\
\text { Surgery }\end{array}$ & Tracheostomy & Not VOC & - & $\begin{array}{l}\bullet \mathrm{ETT} \\
(22.53) \\
\bullet \text { floor } \\
(28.19) \\
\end{array}$ & 68 & - floor at 2 metres & 4 \\
\hline 24 & $70-79$ & $\mathrm{~F}$ & $62(2)$ & $\begin{array}{l}\text { General } \\
\text { Surgery }\end{array}$ & $\begin{array}{l}\text { Tracheostomy, } \\
\text { gastroscopy, insertion } \\
\text { of gastrostomy tube }\end{array}$ & Not VOC & 32.94 & $\begin{array}{l}\text {-ETT (20.7) } \\
\text {-floor } \\
(20.9)\end{array}$ & 117 & $\begin{array}{l}\text { - clamps and } \\
\text { scissors } \\
\text { - Petri dish }\end{array}$ & 5 \\
\hline 25 & $70-79$ & $M$ & 4 & GI & Gastro duodenoscopy & Alpha & 18.62 & $\begin{array}{l}- \text { Gastrosco } \\
\text { pe }(30.56)\end{array}$ & 62 & $\begin{array}{l}\text {-Petri dish } \\
\text {-floor }\end{array}$ & 3 \\
\hline 26 & $60-69$ & $\mathrm{~F}$ & 2 & Burn & $\begin{array}{l}\text { Burn reconstruction } \\
\text { (intubation and } \\
\text { extubation) }\end{array}$ & $\begin{array}{l}\text { Not } \\
\text { tested }\end{array}$ & - & $\begin{array}{l}\bullet \mathrm{ETT} \\
(24.88)\end{array}$ & 142 & $\begin{array}{l}\text {-floor } \\
\text {-face shield } \\
\text { (surgeon) }\end{array}$ & 7 \\
\hline 27 & $70-79$ & $M$ & 2 & Burn & $\begin{array}{l}\text { Debridement, graft } \\
\text { lower abdomen, } \\
\text { thighs } \\
\text { (intubation and } \\
\text { extubation) }\end{array}$ & $\begin{array}{l}\text { Beta/ } \\
\text { Gamma }\end{array}$ & 26.69 & $\begin{array}{l}\cdot \text { ETT } \\
(24.32) \\
\bullet \text { floor } \\
(24.97) \\
\cdot \text { Petri dish } \\
\text { UTM (28.4) } \\
\end{array}$ & 173 & $\begin{array}{l}\text {-scalpel blade, } \\
\text { scissors and clamps }\end{array}$ & 4 \\
\hline 28 & $20-29$ & $M$ & 2 & Plastics & $\begin{array}{l}\text { Hand surgery } \\
\text { (regional block) }\end{array}$ & $\begin{array}{l}\text { Not } \\
\text { tested }\end{array}$ & 35.29 & - & 136 & •floor & 5 \\
\hline 29 & $60-69$ & $\mathrm{~F}$ & 1 & Plastics & Debridement and graft & Alpha & 36.01 & - & 217 & - dermatome •floor & 6 \\
\hline
\end{tabular}




\begin{tabular}{|c|c|c|c|c|c|c|c|c|c|c|c|}
\hline & & & & & $\begin{array}{l}\text { (arrived in OR } \\
\text { intubated and left } \\
\text { intubated) }\end{array}$ & & & & & & \\
\hline 30 & $60-69$ & $M$ & 14 & $\begin{array}{l}\text { Cardiac } \\
\text { Surgery }\end{array}$ & $\begin{array}{l}\text { Aortic valve } \\
\text { replacement (not } \\
\text { extubated) }\end{array}$ & Not VOC & 32.98 & - & 285 & $\begin{array}{l}\text {-thoracic retractor } \\
\text { - floor }\end{array}$ & 6 \\
\hline 31 & $70-79$ & $M$ & 2 & $\begin{array}{l}\text { Vascular } \\
\text { Surgery }\end{array}$ & $\begin{array}{l}\text { Carotid } \\
\text { endarterectomy } \\
\text { (intubation and } \\
\text { extubation) }\end{array}$ & $\begin{array}{l}\text { Not } \\
\text { tested }\end{array}$ & - & - & 178 & $\begin{array}{l}- \text { ETT } \\
\text {-floor } \\
\text { •face shield } \\
\text { (surgeon) }\end{array}$ & 4 \\
\hline 32 & $40-49$ & $M$ & 0 & $\begin{array}{l}\text { Neuro } \\
\text { Surgery }\end{array}$ & $\begin{array}{l}\text { Decompressive } \\
\text { Craniotomy } \\
\text { (arrived in OR } \\
\text { intubated and left } \\
\text { intubated) }\end{array}$ & $\begin{array}{l}\text { Not } \\
\text { tested }\end{array}$ & - & - & 77 & •floor & 4 \\
\hline
\end{tabular}

Legend:

*Patient consent was obtained

Abbreviations:

Yrs, years; VOC, variant of concern; NP, nasopharyngeal; Ct, cycle threshold: the number of cycles required for the fluorescent signal to cross the threshold in RTPCR (a lower Ct would indicate a higher viral load); HCW, health care worker; M, male; F, female; OR, operating room; bilat, bilateral; ETT, endotracheal tube; n/a, not available; OB, Obstetrics; Ortho, Orthopedic Surgery; TAHBSO, total abdominal hysterectomy bilateral salpingo-oophorectomy; Alpha, Alpha variant (United Kingdom, B.1.1.7); ORIF, open reduction internal fixation; GI, gastrointestinal; Beta/Gamma, Beta or Gamma variant (South African, B.1.351 or Brazilian, P.1), UTM, universal transport medium

${ }^{a}$ The mean Ct value of the initial patient NP swab was $21.72,95 \% \mathrm{Cl} 16.90-27.29$ and $29.9695 \% \mathrm{Cl} 27.07-33.43$ respectively in the group of patients that had positive samples (evidence of SARS-CoV-2 RNA) and the group that had all samples negative (Mann-Whitney $\mathrm{U}$ test, $\mathrm{p}=0.007$ ).

${ }^{b}$ The mean Ct value of the initial patient NP swab was 24.52 (95\% Cl: $\left.18.72-30.99\right)$ and 28.41 (95\% Cl: $25.35-30.33$ ) respectively in the group of patients that were known VOC and the group that included known non-VOC and unknown/untested status (Mann-Whitney $U$ test, $p=0.4561$ ).

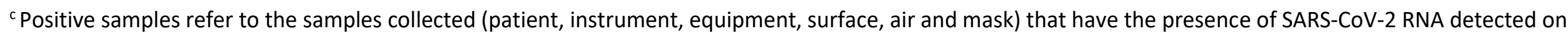
real time RT-PCR (reverse transcriptase polymerase chain reaction)

${ }^{\mathrm{d}}$ Negative samples refer to the samples collected (patient, instrument, equipment, surface, air and mask) that do not have the presence of SARS-CoV-2 RNA detected on real time RT-PCR

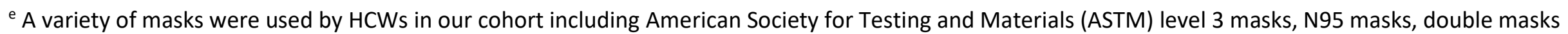
(inner mask sampled) or masks worn under face shields. Of 143 masks: 51 from nurses, 31 from anesthetists, 32 from surgeons and 29 from surgical house staff. 
Table II: Positive tests for SARS-CoV-2 RNA (number of positive samples/number of patients or cases sampled)

\begin{tabular}{|c|c|c|c|c|c|c|c|c|c|c|c|c|}
\hline $\begin{array}{l}\text { Surgical } \\
\text { Service } \\
\text { (No. of } \\
\text { cases) }\end{array}$ & $\begin{array}{l}\text { Peritoneal } \\
\text { fluid }^{a}\end{array}$ & $\begin{array}{l}\text { Vaginal } \\
\text { fluid }^{a}\end{array}$ & $\begin{array}{l}\text { Myometria } \\
\text { I swab }^{\text {a }}\end{array}$ & $\begin{array}{l}\text { Placenta } \\
\text { swab }^{\text {a }} \\
\text { (fetal } \\
\text { side) }\end{array}$ & $\begin{array}{l}\text { Surgical } \\
\text { instruments }^{\text {a }}\end{array}$ & $\mathrm{ETT}^{\mathrm{a}}$ & $\begin{array}{l}\text { Cautery } \\
\text { filter }^{a}\end{array}$ & $\begin{array}{l}\text { Air sample } \\
\text { from GilAir } \\
\text { pump filter }\end{array}$ & $\begin{array}{l}\text { Petri dish } \\
\text { UTM (passive } \\
\text { air sampling) }^{\mathrm{a}}\end{array}$ & $\begin{array}{l}\text { Floor } \\
\text { swab }^{\text {b }}\end{array}$ & $\begin{array}{l}\text { Face } \\
\text { shield }^{a}\end{array}$ & $\begin{array}{l}\text { Masks } \\
\text { a }\end{array}$ \\
\hline $\begin{array}{l}\text { Obstetrics } \\
\mathrm{N}=9\end{array}$ & $1 / 5$ & $1 / 7$ & $1 / 4$ & $1 / 7$ & -- & $1 / 1$ & $0 / 4$ & $0 / 5$ & -- & $0 / 14$ & $0 / 1$ & $0 / 34$ \\
\hline $\begin{array}{l}\text { Gynecology } \\
\text { Oncology } \\
\mathrm{N}=2\end{array}$ & -- & -- & -- & -- & $1 / 1$ & $1 / 2$ & $0 / 2$ & $0 / 3$ & -- & $1 / 4$ & -- & $0 / 11$ \\
\hline $\begin{array}{l}\text { Orthopedics/ } \\
\text { Trauma } \\
\mathrm{N}=7\end{array}$ & -- & -- & -- & -- & $0 / 5$ & $1 / 1$ & $0 / 6$ & $0 / 11$ & $0 / 4$ & $1 / 14$ & -- & $0 / 31$ \\
\hline $\begin{array}{l}\text { General } \\
\text { Surgery } \\
\mathrm{N}=2\end{array}$ & $0 / 1$ & -- & -- & -- & -- & $0 / 1$ & $0 / 2$ & $0 / 4$ & -- & $0 / 4$ & $0 / 1$ & $0 / 9$ \\
\hline $\begin{array}{l}\text { Tracheo- } \\
\text { stomy } \\
\mathrm{N}=4\end{array}$ & -- & -- & -- & -- & $0 / 1$ & $3 / 4$ & $0 / 4$ & $0 / 8$ & $0 / 1$ & $2 / 8$ & -- & $0 / 19$ \\
\hline $\begin{array}{l}\text { Gastro- } \\
\text { enterology } \\
\mathrm{N}=1\end{array}$ & -- & -- & -- & -- & $1 / 1$ & -- & -- & $0 / 2$ & $0 / 1$ & $0 / 2$ & -- & $0 / 3$ \\
\hline $\begin{array}{l}\text { Burn/Plastic } \\
\text { Surgery } \\
\mathrm{N}=3\end{array}$ & -- & -- & -- & -- & $0 / 2$ & $2 / 2$ & $0 / 3$ & $0 / 8$ & $1 / 1$ & $1 / 8$ & $0 / 1$ & $0 / 22$ \\
\hline $\begin{array}{l}\text { Cardiac/ } \\
\text { Vascular } \\
\text { Surgery } \\
\mathrm{N}=2\end{array}$ & -- & -- & -- & -- & $0 / 1$ & $0 / 1$ & $0 / 2$ & $0 / 4$ & -- & $0 / 4$ & $0 / 1$ & $0 / 10$ \\
\hline $\begin{array}{l}\text { Neuro } \\
\text { Surgery } \\
\mathrm{N}=1\end{array}$ & -- & -- & -- & -- & -- & -- & $0 / 1$ & $0 / 2$ & -- & $0 / 2$ & -- & $0 / 4$ \\
\hline $\begin{array}{l}\text { Total: } 32 \\
\text { patients }\end{array}$ & $1 / 6$ & $1 / 7$ & $1 / 4$ & $1 / 7$ & $2 / 11$ & $8 / 12$ & $0 / 24$ & $0 / 47$ & $1 / 7$ & $5 / 60$ & $0 / 4$ & $0 / 143$ \\
\hline
\end{tabular}


Legend:

Abbreviations:

-- (empty cell), sample was either: not taken, not applicable or patient consent was not obtained; ETT, endotracheal tube; UTM, universal transport medium; Plastics, Plastic Surgery;

${ }^{a}$ number of positive tests/number of cases sampled

${ }^{b}$ number of positive tests/number of tests performed (1-2 tests per surgical/obstetrical case) 